\title{
Heterogeneity in dominant anterior segment malformations
}

Gerd E Holmström, William P Reardon, Michael Baraitser, John S Elston, David S Taylor

\begin{abstract}
Peters' anomaly is usually a sporadic or autosomal recessive condition. We present three families whose members had dominantly inherited anterior segment anomalies with variable expression, including typical Peters' anomaly in at least one family member. Slitlamp examination of parents and family members of children with Peters' anomaly is therefore important to exclude dominant inheritance.
\end{abstract}

A variety of anomalies may be seen as a result of disturbances of the development of the anterior segment of the eye, including Peters' anomaly, Rieger's anomaly, Axenfeld's anomaly, and sclerocornea. Many individual cases fit into the more clearly defined patterns or syndromes but they often overlap, defying specific description.

Peters' anomaly consists of a central corneal leucoma, a central defect of Descemet's membrane, and synechiae between the iris and the cornea.' The affected cornea is rarely vascularised, and the peripheral cornea is clear, though scleralisation of the limbus is common. ${ }^{2}$ Keratolenticular adherence with shallowing of the anterior chamber may be seen. ${ }^{23} 80 \%$ of the cases are bilateral and glaucoma may occur in $50 \%$ of the cases. ${ }^{4}$ Other associated findings include congenital cataract, which may be related to the corneal opacity, microphthalmos, coloboma, cornea plana, sclerocornea, and dysgenesis of the angle and the iris. ${ }^{3-5}$ Congenital perforation of the cornea has also been reported. ${ }^{67}$ Associated systemic findings affecting the central nervous system, cardiovascular system, urogenital system, digestive system, skull and face, and limbs are reported. ${ }^{4}$ Histologically the posterior cornea shows the most significant changes. The periphery is normal, but the central part shows an absence or marked attenuation of the endothelium and Descemet's membrane. ${ }^{23}$ Changes in the angle, in the form of numerous iris processes adherent to the trabecular meshwork, have also been mentioned. ${ }^{8}$

Sclerocornea was first described as an isolated congenital anomaly in $1933 . .^{\circ}$ It often occurs together with cornea plana or other ocular anomalies, including microphthalmos, anomalies of the anterior chamber, glaucoma, and coloboma. ${ }^{210}{ }^{11}$ In $90 \%$ of the cases sclerocornea is bilateral. ${ }^{2}$ It may affect either the peripheral or the entire cornea, ${ }^{12}$ which assumes an opaque appearance approaching that of the sclera. Macroscopically the opacity usually extends through the full thickness of the cornea." The cornea is vascularised superficially, but the process may extend deeply. ${ }^{12}$ Histopathologically the lamellar organisation of the corneal stroma is lost, and similarities to scleral tissues with irregularly arranged collagen fibrils of variable dimensions are seen instead. ${ }^{10}{ }^{12-14}$ Elastic fibres have been described in the anterior stroma. ${ }^{12}$ The corneal endothelium and the Descemet's membrane are attenuated, incomplete, or absent..$^{12-14}$

A prominent Scwalbe's line, sometimes called posterior embryotoxon, has been reported in $8-32 \%$ of otherwise normal eyes. ${ }^{415} 16$ However, Axenfeld ${ }^{17}$ used the term 'embryotoxon corneae posterius' when he described a patient with a whitish, prominent line in the posterior periphery of the cornea, close to the limbus, and with iris strands up to this line. Subsequently a prominent Schwalbe line in combination with iris strands to the line has been called Axenfeld's anomaly. It is associated with glaucoma in $50 \%$, ${ }^{18}$ this condition being known as Axenfeld's syndrome.

In 1935 Rieger described cases with iris changes including hypoplasia, corectopia, and hole formation, in addition to findings consistent with Axenfeld's anomaly. ${ }^{19}$ Subsequently this combination has been known as Rieger's

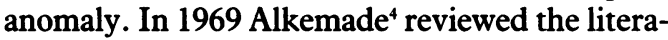
ture together with a study of patients with 'dysgenesis mesodermalis of the iris and the cornea'. A detailed description of Rieger's anomaly was given, the main constituents being hypoplasia of the iris stroma and abnormalities of the iridocorneal angle - that is, a prominent Schwalbe's line with iris strands extending over the angle to the Schwalbe ring. Glaucoma occurs in $60 \%$ of cases, ${ }^{4}$ and an ill defined iridocorneal junction is commonly seen. ${ }^{4}$ The cornea is often normal, but microcornea or macrocornea may be seen. ${ }^{4}$ Peripheral opacities of the cornea at the site of the irideocorneal adhesions are described ${ }^{4}$ as are central leucomas. ${ }^{4021}$ Cornea guttata has also been mentioned. ${ }^{22}$ Pupil abnormalities are frequent (72\%); abnormalities in shape, size, and location are seen as well as polycoria. ${ }^{4}$ Ectropion uveae is described ${ }^{22}$ and so are coloboma of the iris $^{222}$ and lens abnormalities. Epicapsular stars on the anterior lens surface, ${ }^{422} 24$ colobomas, ${ }^{422}$ subluxation, ${ }^{4025}$ cataracts of many types, ${ }^{42022}$ and posterior lens opacities associated with anterior persistent hyperplastic primary vitreous. ${ }^{26}$ Rarely other ocular anomalies may be associated: disc anomalies, chorioretinal colobomas, macular degeneration, choroidal hypoplasia, and retinal detachment. ${ }^{4}$

Some patients with Rieger's anomaly have associated non-ocular developmental defects, particularly of the teeth and facial bones. ${ }^{272}$ The combination of Rieger's anomaly and dental anomalies is called Rieger's syndrome. Many authors fail to distinguish between Rieger's anomaly and Rieger's syndrome. Even the 
original description by Rieger ${ }^{19}$ included at least one case which can be identified as Rieger's syndrome by having teeth abnormalities. However, the term 'Axenfeld-Rieger syndrome' has been proposed, since dental defects also have been noted among patients with findings consistent with Axenfeld's anomaly. ${ }^{29}$

Furthermore, it has been suggested that Axenfeld's and Rieger's syndromes may be different expressions of the same gene. ${ }^{3031}$ The dental defects include microdontia, hypodontia, and oligodontia or anodontia. ${ }^{27}$ Facial abnormalities are a frequent finding, and Rieger described maxillary hypoplasia with flattening of the midface and a short philtrum. ${ }^{19} \mathrm{~A}$ broad, flat nasal root, hypertelorism, and telecanthus have also been described. ${ }^{4}$ Many other systemic abnormalities have been reported ${ }^{43}$ : hand and feet malformations, ${ }^{4334}$ cardiovascular anomalies, ${ }^{43}$ deafness, ${ }^{43}$ mental deficiency, ${ }^{4}$ myopathy, ${ }^{2536}$ skin changes, ${ }^{47}$ umbilical hernias, and hypospadias. $^{2434}$

The genetics of this group of conditions as a whole is problematic. It has been suggested by

\section{Case reports}

Family 1
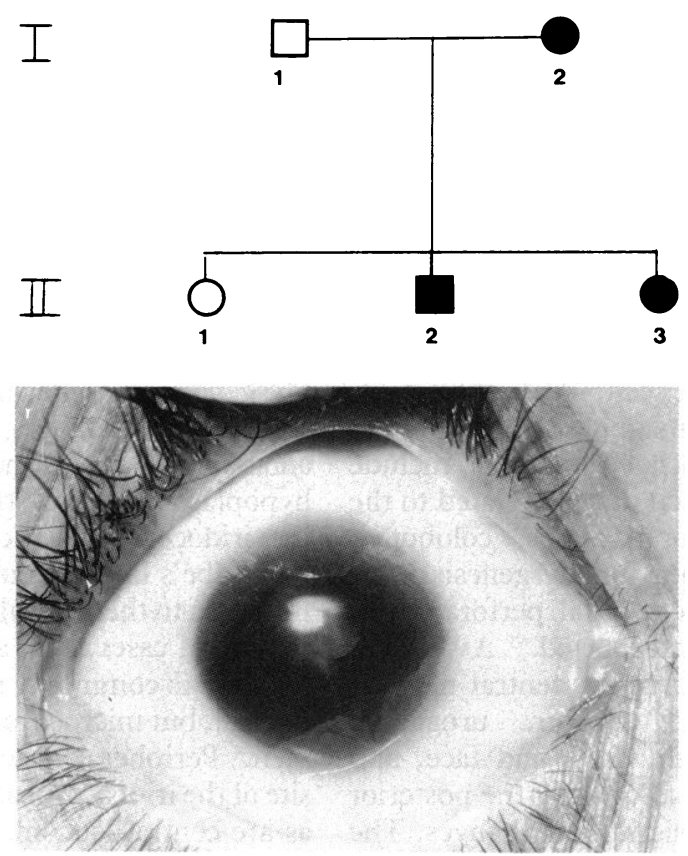

Figure 2 Case I 2. The right eye of the mother has a microcornea, superior and inferior scleralisation, and a cataract. The visual acuity is counting fingers.

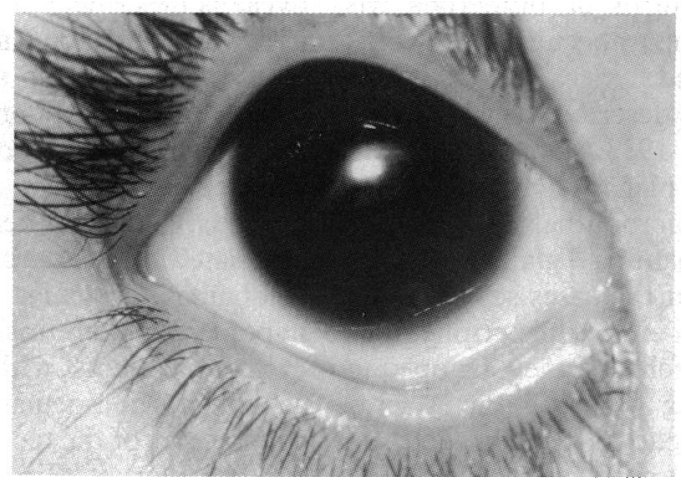

Figure 4 Case II 2. The right eye of this 5-year-old boy has microphthalmos, slight superior and inferior scleralisation, and peripheral iridocorneal adhesions. There is a horizontal nystagmus, and the best visual acuity is 6/36.
Kivlin et al, ${ }^{38}$ who report on several patients with Peters' anomaly in one eye and Axenfeld's anomaly in the other eye, that the various components might represent variable expression of mesodermal dysgenesis. However, these authors do not describe the inheritance of these patients. A variable expressivity of a dominant gene in anterior segment anomalies is reported by Hittner $e t$ al, ${ }^{39}$ Salmon $e t a l,{ }^{40}$ and Green and Johnson..$^{41}$ In the study of Hittner et $a l^{39}$ all family members had cataracts and corneal opacities, but with large phenotypic variation. In the study of Salmon et $a l^{40}$ most affected members had microcornea with cataract but one had a typical Peters' anomaly. In Green and Johnson's study $^{41}$ one patient had Peters' anomaly, others had peripheral scleralisation of the cornea, while most patients had microcornea and cataract.

We report on three families which support the contention that Peters' anomaly, Rieger's anomaly, sclerocornea, and Rieger's syndrome might occasionally be the result of variable expression of the same genetic disorder.

Figure 1 Pedigree data of family 1 . I and II refer to the different generations in the pedigree. $1,2,3$, etc refer to the individuals within a particular generation. $\mathbf{\nabla}=$ affected male. $\square=$ unaffected male. $\mathbf{O}=$ affected female. $\mathrm{O}=$ unaffected female.

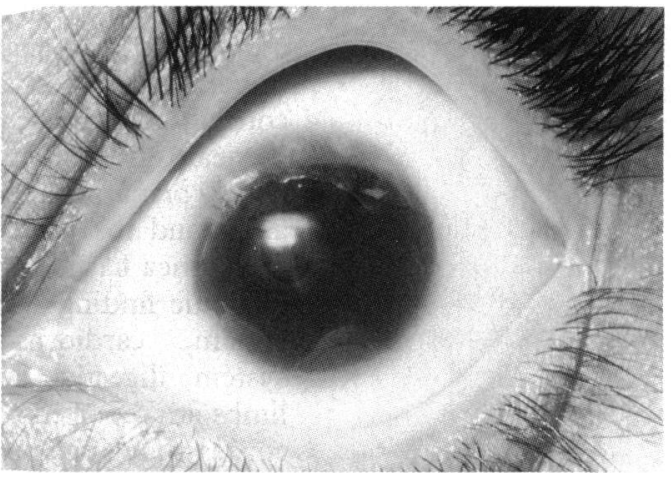

Figure 3 Case I 2. The left eye has a microcornea, superior scleralisation, and aphakia. The vision is 6/36 with glasses $(+13 \cdot 0)$.

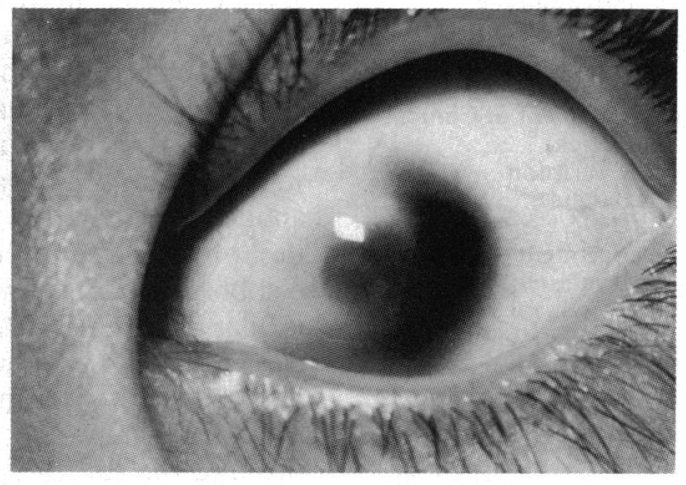

Figure 5 Case II 2. The left eye has microphthalmos, sclerocornea, and peripheral iridocorneal adhesions and can only localise light. 
III 3

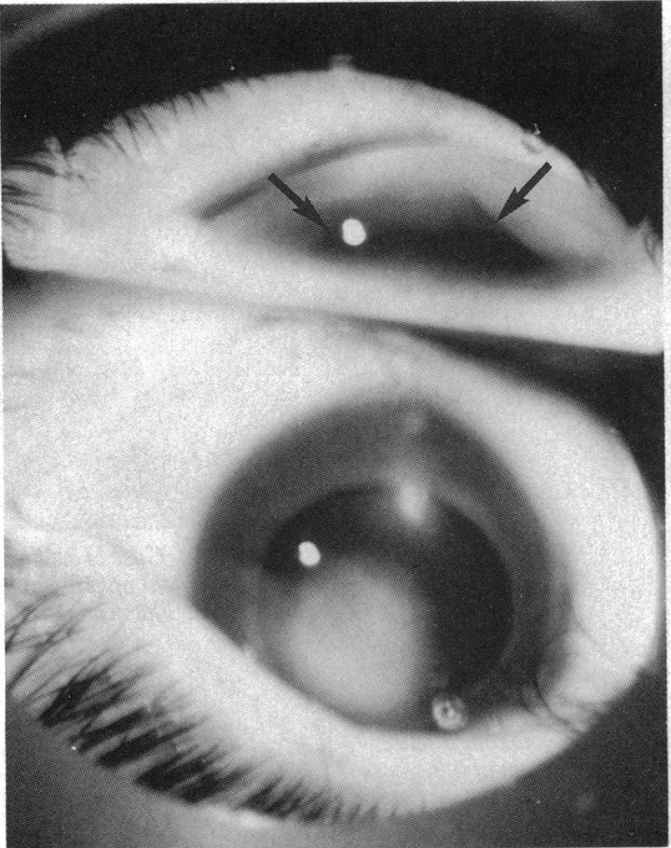

Figure 6 Case III 3. The right eye of this baby has Peters anomaly with a central comeal opacity and lens adhesions to the corneal endothelium seen with gonioscope at 3 months of age. The arrows indicate the border of the lens.

Family 2
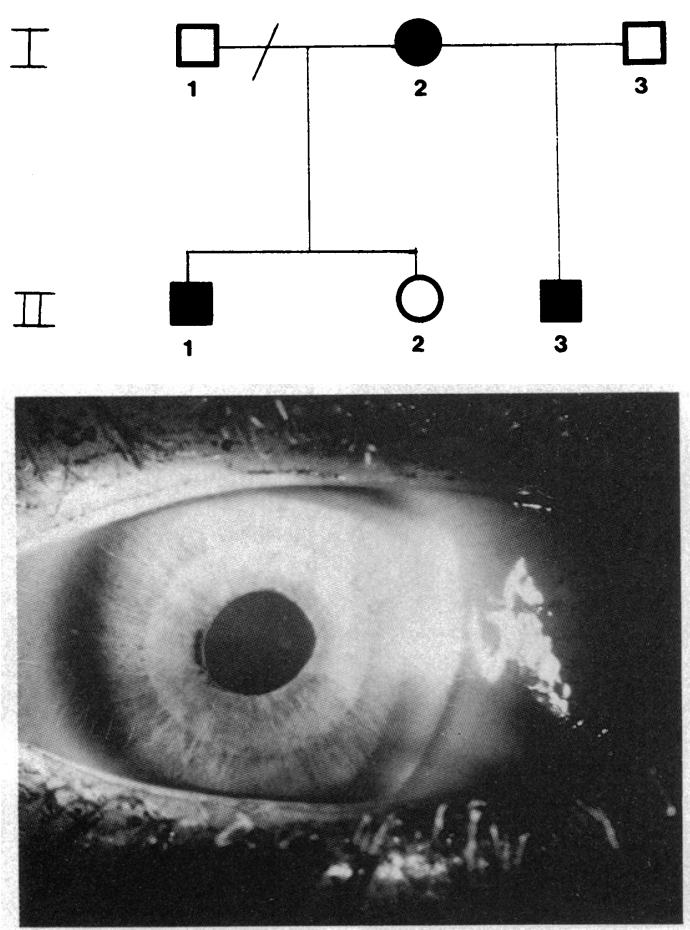

Figure 9 Case I 2. The right eye has iris hypoplasia, posterior embryotoxon, peripheral iridocorneal adhesions, and a visual acuity of $6 / 9$.

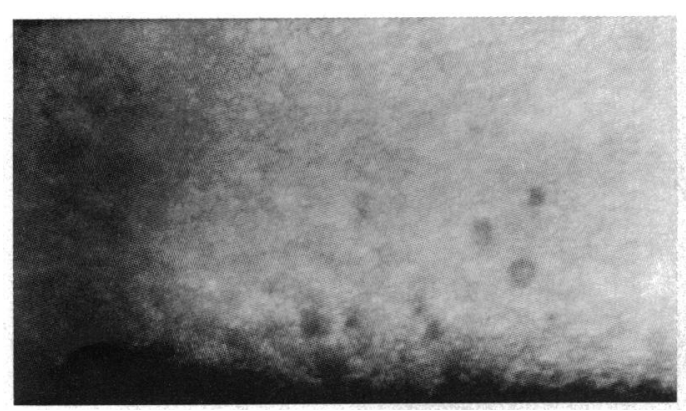

Figure 11 Case I 2. Enlarged, irregular corneal endothelial cells with focal defects.

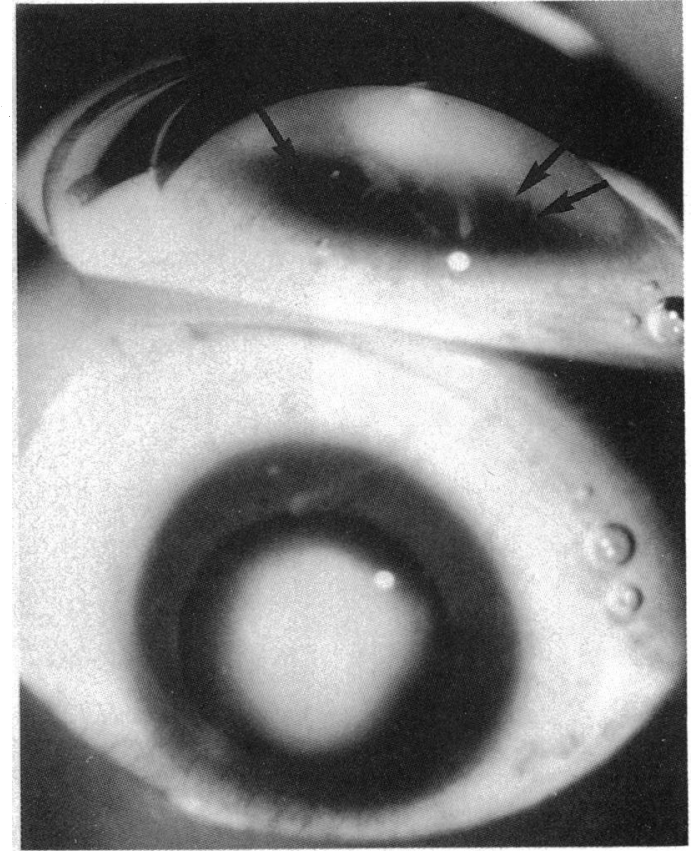

Figure 7 Case III 3. The left eye has Peters' anomaly with a more pronounced corneal opacity and lens adhesions to the cornea seen at gonoscopy. The arrows indicate the border of the lens.

Figure 8 Pedigree data of family 2.

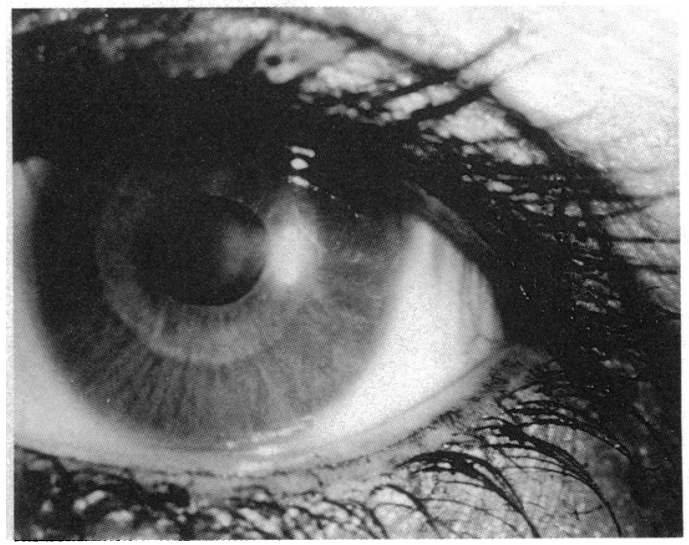

Figure 10 Case I 2. The left eye also has iris hypoplasia, posterior embryotoxon, peripheral iridocorneal adhesions, and a visual acuity of $6 / 12$ ( $-2 \cdot 5$ dioptres).

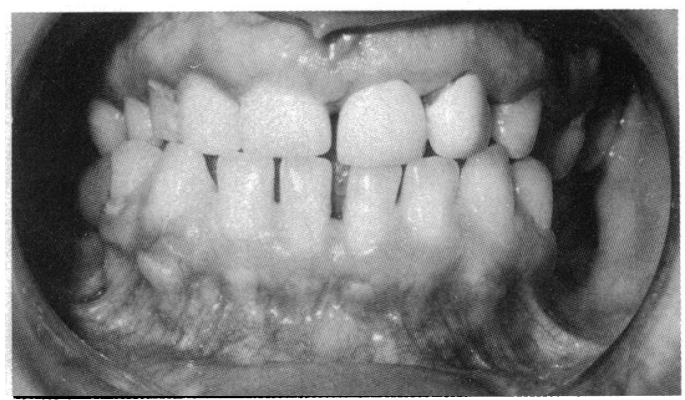

Figure 12 Case I 2. The mother has short clinical crowns of the two frontal teeth, which have been capped, aplasia of the lateral incisors, and a right side cross-bite. 
II 1
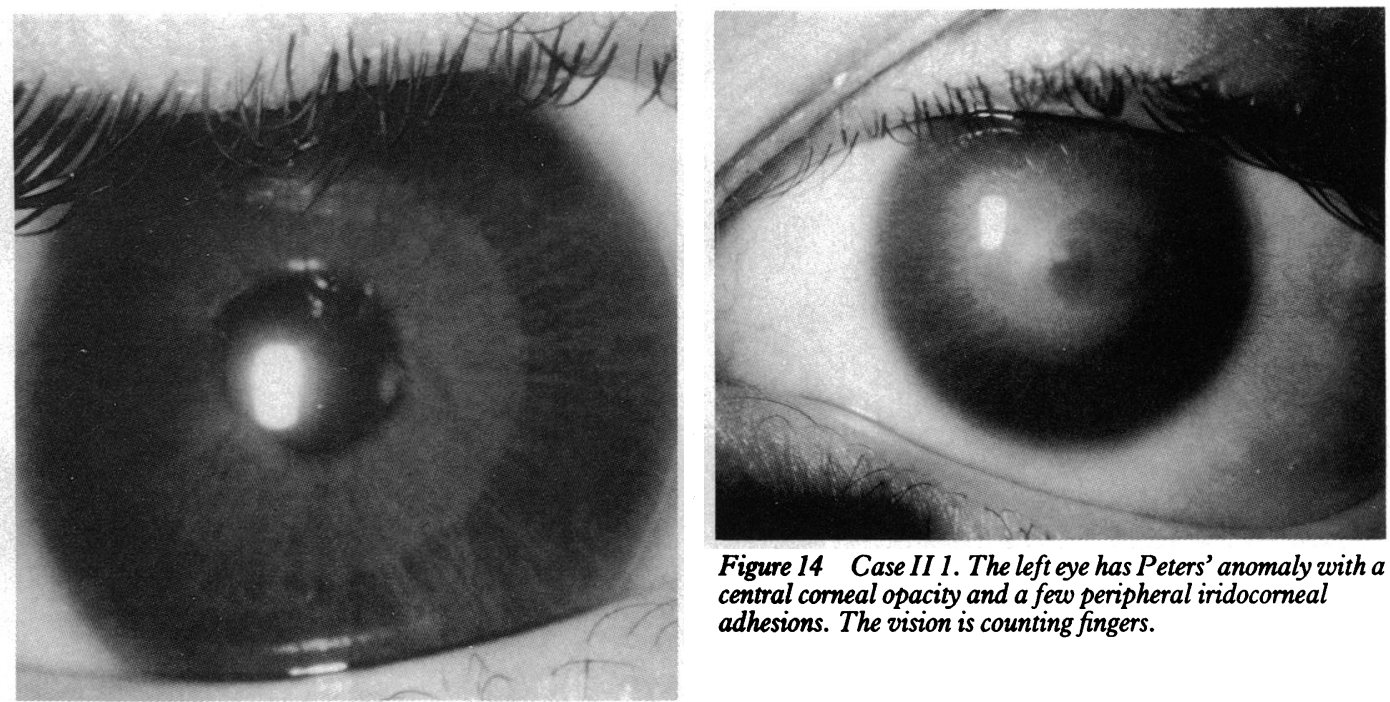

Figure 14 Case II 1. The left eye has Peters' anomaly with a central corneal opacity and a few peripheral iridocorneal adhesions. The vision is counting fingers.

Figure 13 Case II 1. The right eye of this 14-year-old boy has iris hypoplasia, partial posterior embryotoxon, a few peripheral iridocormeal adhesions, and a vision of 6/9.

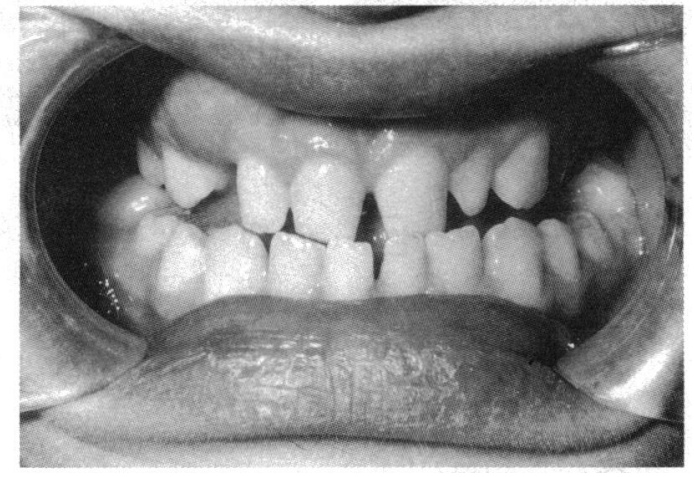

Figure 15 Case II 1. This boy has maxillary hypoplasia, evident by the malocclusion of the teeth. He has also two frontal, capped teeth, two hypoplastic premolars in the lower jaw, and a tiny lateral incisor in the upper jaw.

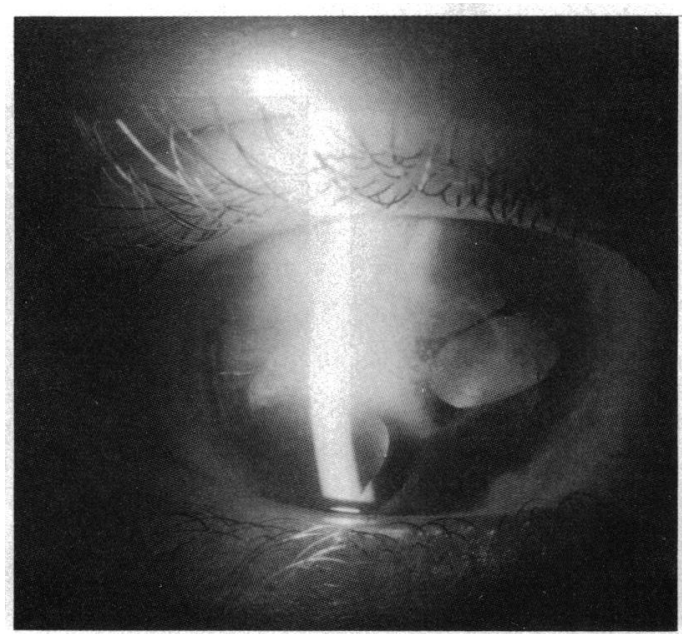

Figure 16 Case II 3. A 7-year-old boy with a right eye with iris hypoplasia, posterior embryotoxon, polycoria, cataract, band keratopathy, glaucoma, and no perception of light.

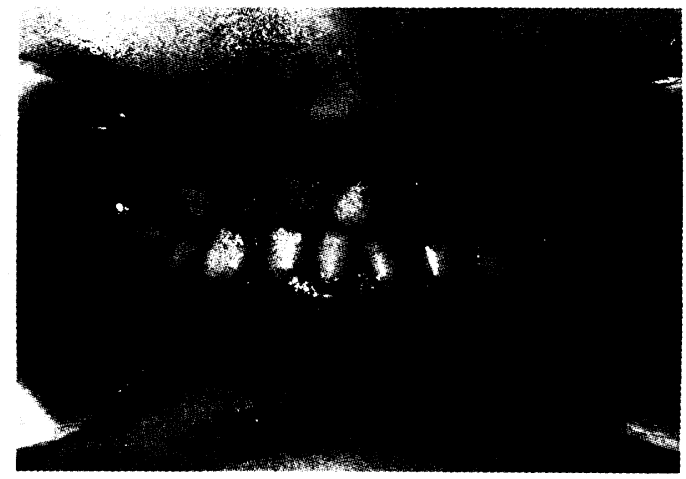

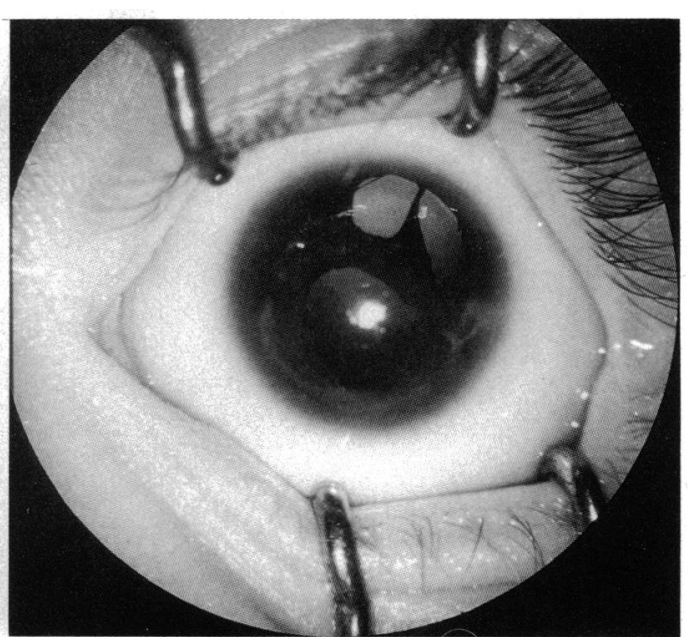

Figure 17 Case II 3. The left eye has iris hypoplasia, posterior embryotoxon, peripheral iridocorneal adhesions, and a vision of 6/9.

Figure 18 Case II 3. This boy has a bilateral cross-bite, which could be related to a maxillary hypoplasia. His dention is primary, and nothing can yet be said of his permanent teeth. 
Family 3

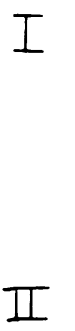

Case I 2. The mother has bilateral iris hypoplasia and partial posterior embryotoxon and normal vision.

Case II 2. A nine-year-old girl has bilateral iris hypoplasia and posterior embryotoxon laterally and $a$ normal vision.
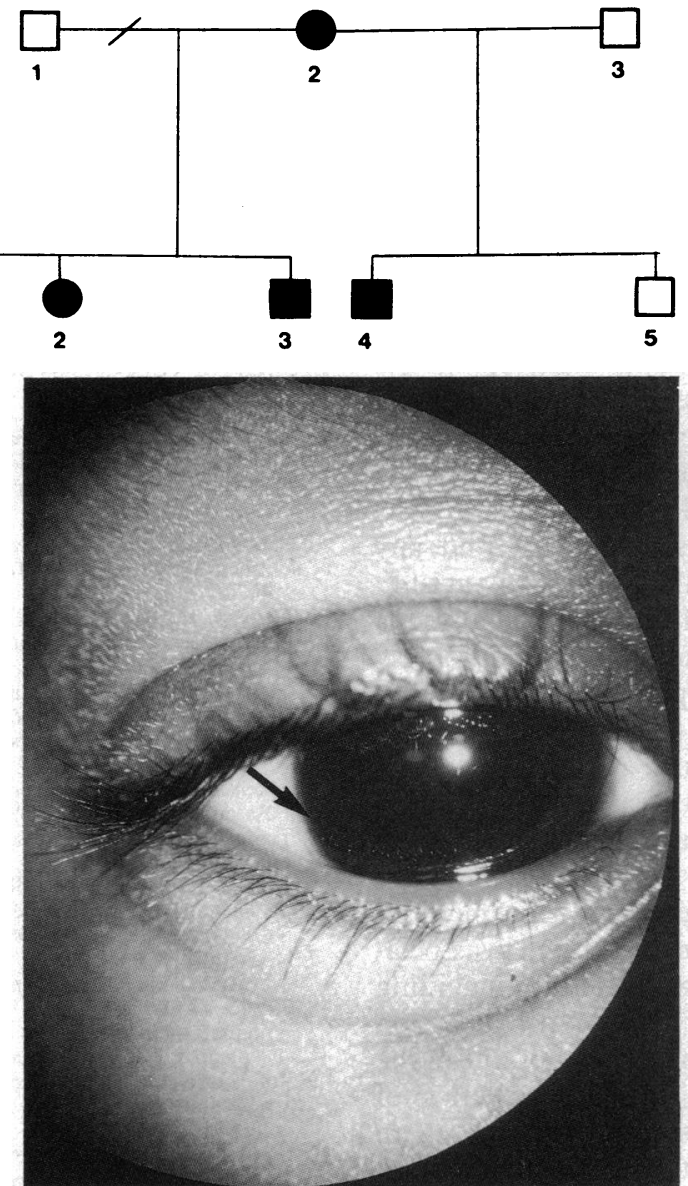

Figure 20 Case II 3. This 7-year-old boy has a right eye with iris hypoplasia, posterior embryotoxon (arrow), and a normal visual acuity.

\section{Discussion}

Anterior segment anomalies are caused by disturbances in the early development of the eye. The optic primordium develops from three different embryonic layers: neural ectoderm, surface ectoderm, and mesoderm (primary mesenchyme). ${ }^{42}$ Neural crest cells, a subpopulation of cells emigrating from the dorsal margin of the neural folds at about the time of neural tube closure, migrate into the primary mesenchyme to form secondary mesenchyme. ${ }^{43}$ Subsequently three successive waves of secondary mesenchyme migrate centrally from the rim of the optic cup to form the corneal endothelium and the trabecular meshwork, the keratocytes, and the anterior iris respectively. ${ }^{44}$ Johnston et $a l^{43}$ showed that neural crest cells are the major contributor to the development of the corneal stroma, the corneal epithelium, the anterior chamber, the iris stroma, and the sclera in chick embryos, and light and electron microscopy studies on the human corneal endothelium also point to a neural crest origin. ${ }^{45}$

Several theories of the pathogenesis of the different anomalies of the anterior segment have been presented. Alkemade ${ }^{4}$ used the term 'mesodermal dysgenesis of the iris and cornea' to describe the pathogenetic mechanism. Reese and Ellsworth $^{46}$ believed that anterior segment anomalies were due to faulty cleavage and introduced the term 'anterior chamber cleavage syn-
Figure 19 Pedigree data of family 3.

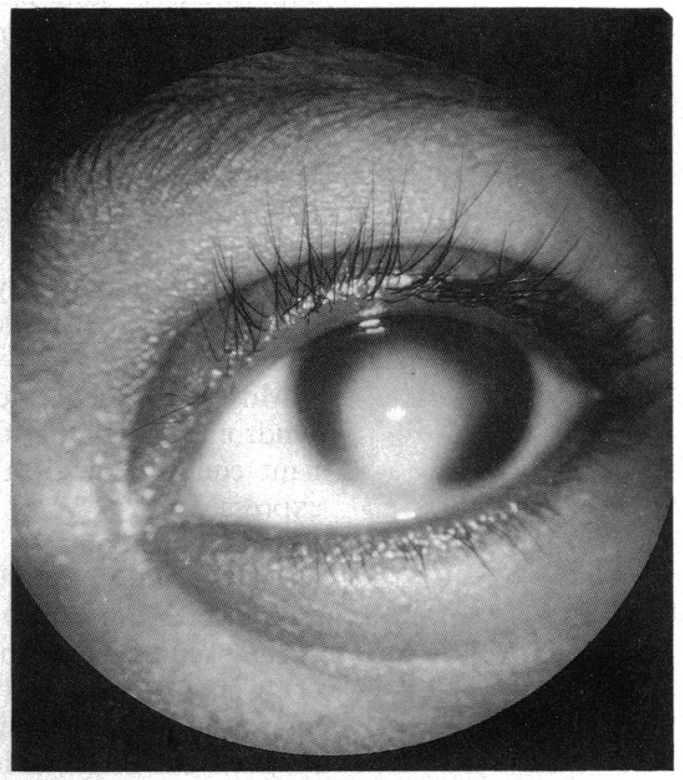

Figure 21 Case II 3. The left eye shows Peters' anomaly with a central corneal opacity, lens opacity, posterior embryotoxon, and glaucoma. There is no perception of light.

drome' to 'include all possible factors such as improper differentiation, absorption, or even shifting or mobilisation of tissue in its developmental stage'. Waring et $a l^{18}$ presented an anatomical description of the anomalies of the anterior segment, based on the 'anterior chamber cleavage' theory, which they called 'a stepladder classification'. However, Kupfer and Kaiser-Kupfer ${ }^{8}$ did not find any embryological basis for this explanation of the anterior cleavage syndrome and instead suggested a disturbance of the migration of the three mesenchymal waves from the optic cup, and the term 'mesenchymal dysgenesis' was proposed by Kenyon. ${ }^{2}$ Bahn et al suggested a classification of corneal disorders based on neural crest origin, where sclerocornea and Axenfeld's, Rieger's, and Peters' anomaly were thought to be caused by abnormal neural crest cell migration. ${ }^{44}$ Neural crest cell disturbances also affect other parts of the body, which explains the systemic symptoms sometimes associated with anomalies of the anterior segment of the eye. ${ }^{8}$

In the families described here the common feature in all three pedigrees is Peters' anomaly in at least one family member. Other affected family members showed Rieger's anomaly, sclerocornea, and other manifestations of anterior segment malformation. Although described in association with a wide variety of 
extraocular abnormalities, ${ }^{38}$ Peters' anomaly is thought to occur most often as an isolated, nongenetic condition. ${ }^{2}$ However, there are some cases which are indisputably familial, and these are mainly composed of multiple affected siblings suggestive of autosomal recessive inheritance. ${ }^{47+8}$ However, dominant inheritance has also been shown, ${ }^{49}{ }^{50}$ and, although single cases of Peters' anomaly have been associated with different chromosome defects including chromosome 4 abnormality, ${ }^{51}$ ring 21 chromosomal abnormality, ${ }^{51}$ and interstitial deletion of the long arm of chromosome $11,,^{52}$ a chromosomal basis is very unlikely to account for most cases.

Axenfeld's anomaly has been reported to be inherited as an autosomal dominant condition. ${ }^{31}$ However, Brear and Insler did not find any inheritable basis of Axenfeld's anomaly at all. ${ }^{53}$ Sclerocornea is most often thought to be a sporadic or dominantly inherited condition. ${ }^{10-12}$ A recessive inheritance pattern has, however, also been mentioned. ${ }^{11}$

Most published evidence points to Rieger's syndrome being inherited as an autosomal dominant condition with a substantial variation in expressivity. ${ }^{+192431345455}$ However, Forsius ${ }^{56}$ found indications of recessive transmission. Rieger's syndrome has been described in association with chromosomal abnormalities, including chromosome 13 deletion, ${ }^{57}$ pericentric inversion of chromosome $6,{ }^{58}$ and an isochromosome of the long arm of autosome $6 .{ }^{59}$ The genetics of Rieger's anomaly is less clear, though there certainly are pedigrees with autosomal dominant transmission of the eye defect. ${ }^{22}{ }^{23}$ In the absence of an offspring study of isolated cases the proportions due to genetic and other causes cannot be apportioned, and the precise contribution of new mutations cannot be quantified.

The genetic counselling problems in these families are evident from pedigree 3 , where the mother (I2) had subtle abnormalities confined to the eyes but her children, who might have been predicted to be at low risk, have inherited Rieger's and Peters' anomalies. In pedigree 1 the mother's eye problems are mainly microcornea and cataract, and yet she is obviously a gene carrier whose children have Peters' and Rieger's anomalies. Even with the lesson of pedigree 3 in mind it would have been very difficult on seeing this woman to have predicted a $50 \%$ offspring risk for her. In view of the hypodontia in pedigree 2 it is easier to say that the condition in this family is Rieger's syndrome. However, the mother's (I2) problems are very subtle, and, as with pedigrees 1 and 3 , accurate predictions as to the offspring risk would have been very difficult before the birth of her first affected child.

It is probable that the mothers in each of these three pedigrees are gene carriers of an autosomal dominant condition for anterior segment anomalies. In pedigrees 1 and 3 the lesions are without extraocular abnormalities, like the pedigrees reported by Fitch and Kabak ${ }^{31}$ and Pearce and Kerr. ${ }^{23}$ The resulting eye defects in our families are remarkably variable, and these three pedigrees serve to emphasise the variability of manifestations that this autosomal dominant gene gives rise to. While further complicating the situation for the genetic counsellor, these pedi- grees demonstrate that Peters', Rieger's, or Axenfeld's anomaly may be seen as part of a dominantly inherited condition without extraocular abnormalities. At present in the absence of extraocular abnormalities there is no way of knowing whether isolated Rieger's, Peters', or Axenfeld's anomalies confined to the eye are part of Rieger's syndrome, and therefore likely to be transmitted to offspring, or not. This genetic counselling dilemma awaits the outcome of linkage studies and the development of gene specific probes for Rieger's syndrome.

We thank Mr J Dart for endothelial studies of family 2 . We are also grateful to the Photographic Department for their help and for support from 'Help a child to see'

1 Peters A. Ueber angeborene Defektbildung der Descemetschen Membran. Klin Monatsbl Augenheilkd 1906; 44: 27schen Mem 105 .

2 Kenyon K. Mesenchymal dysgenesis in Peters' anomaly, sclerocornea and congenital endothelial dystrophy. Exp Eye Res 1975; 21: 125-42.

3 Townsend W. Font R, Zimmerman L. Congenital corneal leukomas. 2. Histopathological findings in 19 eyes with central defect in Descemet's membrane. Am $\mathcal{F}$ Ophthalmol 1974; 77: 192-206.

4 Alkemade P. Dysgenesis mesodermalis of the iris and the cornea. Assen: Van Gorcum, 1969

5 Townsend W. Congenital corneal leukomas. 1. Central defect in Descemet's membrane. Am f Ophthalmol 1974; 77: 80-6.

6 Krause U, Koivisto M, Rantakallio P. A case of Peters' syndrome with sponataneous corneal perforation. $\mathcal{F}$ Pediatr Syndrome with sponataneous corneal

7 Heckenlively J, Kielar R. Congenital perforated cornea in Peters' anomaly. Am $\mathcal{F}$ Ophthalmol 1979; 88: 63-5.

8 Kupfer C, Kaiser-Kupfer M. New hypothesis of developmental anomalies of the anterior chamber associated with glaucoma. Trans Ophthalmol Soc UK 1978; 98: 213-5.

9 Rollet J. Arch Kératites, dégénerations et opacités Cornéennes héréditaires et familiales. Arch Ophthalmol (Paris) 1933; 50: $160-91$.

10 Goldstein J, Cogan D. Sclerocornea and associated congenital anomalies. Arch Ophthalmol 1962; 67: 99-106.

11 Howard R, Abrahams I. Sclerocornea. Am F Ophthalmol 1971; 71: $1254-60$.

12 Elliot J, Feman S, O'Day D, Garber M. Hereditary sclerocornea. Arch Ophthalmol 1985; 103: 676-9.

13 Kanai A, Wood T, Polack F, Kaufman H. The fine structure of sclerocornea. Invest Ophthalmol Vis Sci 1971; 10: 687-94.

14 Kolbert G, Seelenfreund M. Sclerocornea, anterior cleavage syndrome, and trisomy 18 . Ann Ophthalmol 1970; 2: 26-30.

5 Burian H, Braley A, Allen L. Visibility of the ring of Schwalbe and the trabecular zone. Arch Ophthalmol 1955; 53: 767-82.

16 Forsius H, Eriksson A, Fellman J. Embryotoxon corneae posterius in an isolated population. Acta Ophthalmol (Kbh) 1964; 42: 42-9.

17 Axenfeld T. Embryotoxon corneae posterius. Ber Dtsch Ophthalmol Ges 1920; 42: 301-2.

18 Waring G, Rodrigues $M$, Laibson P. Anterior chamber cleavage syndrome. A stepladder classification. Surv Ophthalmol 1975; 20: 3-27.

19 Rieger H, Beiträge zue Kenntnis seltener Missbildungen der Iris. II. Über Hypoplasie des Irisvorderblattes mit Verlagerung und Entrundung der Pupille. Graefes Arch Clin Exp Ophthalmol 1935; 133: 602-35.

20 Falls $\mathrm{H}$. A gene producing various defects of the anterior segment of the eye. Am $\mathcal{F}$ Ophthalmol 1949; 32: 41-52.

21 Wolter JR, Sandall G, Fralick B. Mesodermal dysgenesis of anterior eye: with partially separated posterior embryotoxon. F Pediatr Ophthalmol Strabismus 1967; 4: 41-6.

22 Henkind P, Siegel I, Carr R. Mesodermal Dysgenesis of the anterior segment: Rieger's anomaly. Arch Ophthalmol 1965; 73: 810-7.

23 Pearce W, Kerr C. Inherited variation in Reiger's malformation. Brf Ophthalmol 1965; 49: 530-7.

24 Chisholm I, Chudley A. Autosomal dominant iridogoniodysgenesis with associated somatic anomalies: four-generation family with Rieger's syndrome. Br $\mathcal{F}$ Ophthalmol 1983; 67: 529-34.

25 Busch G, Wieskopf J, Busch K. Dysgenesis mesodermalis et ectodermalis Rieger oder Rieger' sche Krankheit. Klin Monatsbl Augenheilkd 1960; 136: 512-23.

26 Storimans C, Van Schooneveld M. Rieger's eye anomaly and persistent hyperplastic primary vitreous. Ophthalmic Paediatr Genet 1989; 10: 257-62.

27 Rieger H. Erbfragen in der Augenheilkunde. Graefes Arch Clin Exp Ophthalmol 1941; 143: 277-99.

28 Mathis H. Zahnunterzahl und Missbildungen der Iris. Z Stomatol 1936; 34: 895-909.

29 Shields B. Axenfeld-Rieger syndrome: a theory of mechanism and distinctions from the iridocorneal endothelial synand distinctions from the iridocorneal endothelial syn-
drome. Trans Am Ophthalmol Soc 1983; 81: 736-84.

30 Hoskins D, Shaffer R. Rieger's syndrome: a form of iridocorneal mesodermal dysgenesis. $\mathcal{f}$ Pediatr Ophthalmol Strabismus 1972; 9: 26-30.

31 Fitch N, Kaback, $M$. The Axenfeld syndrome and the Rieger syndrome. 7 Med Genet 1978; 15: 30-4. 
32 Wesley R, Baker J, Golnick A. Rieger's syndrome (oligodontia and primary dysgenesis of the iris): clinical features and report of an isolated case. 7 Pediatr Ophthalmol Strabismus 1978; 15: 67-70.

33 Frandsen E. Rieger's syndrome combined with oligodontia and finger deformity. Acta Ophthalmol (Kbh) 1963; 41: 757and 67.

34 Jorgenson R, Levin S, Cross H, Yoder F, Kelly T. The Rieger syndrome. Am $\mathcal{F}$ Med Genet 1978; 2: 307-18.

35 Schmidt-Rederman B, Vogt J. Hypoplasie der Arteria pulmonalis beim Rieger-Syndrom. Klin Padiatr 1976; 188: $554-7$

36 Summit R, Hiatt R, Duenos D, Johnson W. Mesectodermal dysplasia of the iris and the cornea, mental retardation and myopathy: a sporadic case. Birth Defects 1971; 8: 129-35.

37 Gassler H, Berthold H. Ein Beitrag zur Ektodermalen Dysplasie aus Ophthalmologischer Sicht. Klin Monatsbl Augenheilkd 1960;136: 52-65.

38 Kivlin J, Fineman R, Crandall A, Olson R. Peters' anomaly as a consequence of genetic and nongenetic syndromes. Arch Ophthalmol 1986; 104: 61-4.

39 Hittner H, Kretzer F, Antoszyk J, Ferrall R, Metha R. Variable expressivity of autosomal dominant anterior segment mesenchymal dysgenesis in six generations. $A m \mathcal{F}$ Ophthalmol 1982; 93: 57-70.

40 Salmon J, Wallis C, Murray A. Variable expressivity of autosomal dominant microcornea with cataract. Arch Ophthalmol 1988; 106: 505-10.

41 Green J, Johnson G. Congenital cataract with microcornea and Peters' anomaly. Ophthalmic Paediatr Genet 1986; 7: 187-94.

42 Duke-Elder S. System of ophthalmology. St Louis: Mosby, 1964; 3: 29-32.

43 Johnston M, Noden D, Hazelton R, Coulombre J, Coulombre A. Origins of avian ocular and periocular tissues. Exp Eye Res 1979; 29: 27-43.

44 Bahn C, Falls H, Varley G, Meyer R, Edelhauser H, Bourne W. Classification of corneal endothelial disorders based on W. Classification of corneal endothelial disorders based
neural crest origin. Ophthalmology 1984; 91: 558-63.

45 Snip R, Green R, Kreutzer E, Hirst L, Kenyon K. Posterior corneal pigmentation and fibrous proliferation by iris melanocytes. Arch Ophthalmol 1981; 99: 1232-8.

46 Reese A, Ellsworth R. The anterior chamber cleavage syndrome. Arch Ophthalmol 1966; 75: 307-18.

47 Boel M, Timmermans J, Emmery L, Dralands G, Fryns J, van der Berghe $\mathbf{H}$. Primary mesodermal dysgenesis of the cornea (Peters' anomaly) in two brothers. Hum Genet 1979; $51: 237-$
40 .

48 Cross $H$. Penetrance of variability in anterior chamber malformations. Birth Defects 1979; 15: 131-44.

49 Kresca L, Goldberg M. Peters' anomaly: dominant inheritance in one pedigree and dextrocardia in another. $\mathcal{F}$ Pediatr Ophthalmol Strabismus 1978; 15: 141-6.

50 DeRespins $P$, Wagner R. Peters' anomaly in a father and son. Am $\mathcal{F}$ Ophthalmol 1987; 104: 545-6.

51 Cibis G, Waeltermann J, Harris D. Peters' anomaly in association with ring 21 chromosomal abnormality. $A m \mathcal{F}$ Ophthalmol 1985; 100: 733-4.

52 Bateman B, Maumenee I, Sparkes R. Peters' anomaly associated with partial deletion of the long arm of chromosome 11 . Am $\mathcal{F}$ Ophthalmol 1984; 97: 11-5.

53 Brear R, Insler M. Axenfeld's syndrome associated with systemic abnormalities. Ann Ophthalmol 1985; 17:291-4.

54 Feingold M, Shiere F, Fogels H, Donaldson D. Rieger's syndrome. Pediatrics 1969; 44: 564-9.

55 McKusick V. Mendelian inheritance in man. 8 th ed. Baltimore: Johns Hopkins University Press, 1988.

56 Forsius H. Visibility of anterior border-ring of Schwalbe in congenital corneal anomalies: tumours of the limbus and dental anomalies. Acta Ophthalmol (Kbh) 1963; 41: 97-107.

57 Stathacopoulus R, Bateman B, Sparkes R, Hepler R. The Rieger syndrome and a chromosome 13 deletion. 7 Pediatr Ophthalmol Strabismus 1987; 24: 198-203.

58 Heinemann M, Breg R, Cotlier E. Rieger's syndrome with pericentric inversion of chromosome 6. Br $\mathcal{F}$ Ophthalmol 1979; 63: 40-4.

59 Tabbara K, Khouri F, Der Kaloustian V. Rieger's syndrome with chromosomal anomaly. Can f Ophthalmol 1973; 8: 488- 